\title{
Valuation practices under business rescue circumstances in South Africa
}

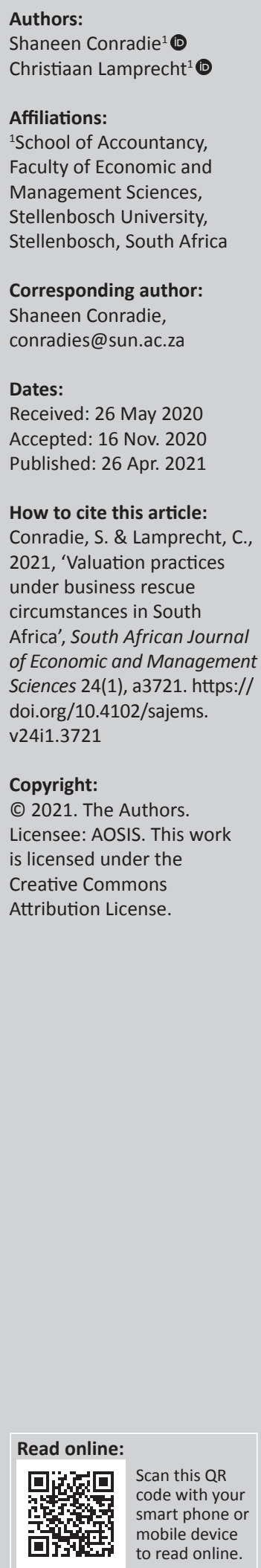

Background: A business rescue plan should indicate the benefits of adopting a business rescue plan as opposed to the benefits of immediate liquidation. Performing a valuation is thus a vital aspect of the business rescue process as the estimated values determine the amount to be divided between creditors and, if possible, shareholders. Conventional valuation methods have the underlying assumption that the business is a going concern (based on liquidy and solvency tests). However, a company in business rescue is not necessarily a going concern, nor in liquidation, leaving the company in a grey area in terms of valuation.

Aim: This research explored how the business rescue value of a financially distressed company is determined.

Setting: The setting for this study was South Africa.

Method: Thematic analysis of qualitative data collected through 11 semi-structured interviews with senior business rescue practitioners (BRPs).

Results: When the intention is to return the company to solvency, the BRPs prepared a short-term, undiscounted cash flow budget to determine the business rescue value, but without including a terminal value in the projected cash flows. In contrast, when the intention is to obtain a better return compared to immediate liquidation, BRPs follow an asset approach to determine the business rescue value. The results also showed that the business, digital and relational acumen of the BRP is a major influencer in the business rescue value.

Conclusion: The financial elements identified and substantiated in this study may serve as best practice guidance in the business rescue industry and lead to an expansion of the existing valuation theory.

Keywords: Business rescue practitioner; business rescue value; Chapter 6; Companies Act; financial distress; going concern; liquidation; valuation.

\section{Introduction}

South African companies in financial distress may file for business rescue in terms of Chapter 6 of the South African Companies Act No. 71 of 2008. The Companies Act (RSA 2008:s150[b][vi]) requires, among other things, that an appointed business rescue practitioner (BRP) prepare a business rescue plan to show the benefit of adopting the business rescue plan as an alternative to immediate liquidation. The business rescue plan should indicate to the creditors that a company is worth more 'alive' than 'dead'. In other words, that if the creditors file for immediate liquidation, they will receive less than they would receive through a reorganisation (in South Africa [SA] referred to as a business rescue) (Altman \& Hotchkiss 2006:8). Thus, showing the benefits in the form of a valuation of the company in business rescue becomes a vital aspect of a restructuring process, since the estimated value of the company determines the size of the pie to be divided between the creditors and, if possible, the shareholders (Altman \& Hotchkiss 2006:103; Harvey 2011:181; TMA-US 2016:202).

\section{A value uncertainty in practice}

According to Practice Note 1 of the Turnaround Management Association (TMA) of SA, the BRP should, while preparing the liquidation value, also prepare a draft business rescue distribution value based on preliminary assumptions and scenarios for the business rescue plan (Migwalla 2017). A Gauteng High Court judgement showed that the court was uncertain how a BRP could obtain a better market value for assets in business rescue than a liquidator (Bradstreet 2013:45). It is precisely this uncertainty that is the aim of this article, namely how the BRP determines the business rescue value of a financially distressed South African company for inclusion in the business rescue plan. 
When a business goes into financial distress, valuation becomes a complicated matter, one that has not yet been comprehensively analysed (Crystal \& Mokal 2006:1; Hrdý \& Simek 2012:121, 131). Conventional valuation techniques are available to the BRP. However, Damodaran (2009:11) states that analysts often find that the tools and approaches that served them adequately for healthy companies do not hold in a distress scenario. The problem is even worse in a sector with a history of financial distress, since analysts are often slow to let go of old rules of thumb (ROT) and metrics (Damodaran 2009:11).

\section{The two business rescue avenues}

In SA, the Companies Act allows for two possible outcomes from a business rescue. In simple terms, Goal 1 refers to an instance in which a company is restructured (or revitalised) in order to continue as a going concern on a solvent basis, while Goal 2 requires that creditors receive a better return as compared to immediate liquidation (RSA 2008:s128[1][b] [iii]). A BRP may achieve a better return under Goal 2 through either selling the assets of the company as a functioning unit to another party or through a controlled wind-down of assets (Harvey 2011:182). Loubser (2013:448) submitted that one cannot assume that selling a company as a going concern in business rescue would always result in a higher return than selling assets in a break-up sale. Even if one assumes that a better price can be obtained when selling a going concern in business rescue, business rescue costs such as practitioner fees and employee remuneration may erode the benefit, and the company could just as well have gone into liquidation straight away. To complicate matters, the BRP is also under tremendous time pressure to publish the business rescue plan (Pretorius 2016:491; RSA 2008:s150), as there is a negative correlation between the time that elapses and the asset value in a distressed company (Rajaram, Singh \& Sewpersadh 2018). It may therefore not be possible to perform a comprehensive valuation of the company using the conventional valuation techniques.

\section{Defining the term business rescue value}

According to the Oxford English Dictionary (Oxford 2017), the word 'benefit' means an advantage or profit gained from something. The word benefit may, therefore, include both monetary and non-monetary advantages or gains. This is also applicable in business rescue as the benefit of business rescue goes beyond the monetary benefit that may be available to the creditors. For example, it will also include the benefit that a successfully completed business rescue will, under Goal 1, prevent job losses (Conradie \& Lamprecht 2018; Loubser 2010:560; Marsden \& Laher 2018). The nonmonetary elements of business rescue success have been sufficiently researched; therefore, this research focuses on the monetary benefit of business rescue. Throughout this article, the authors used the term business rescue value, which refers to the value (monetary benefit) determined as the alternative to immediate liquidation.

\section{Research aim, question and objective}

To address the problem of conventional valuation methods that may not be applicable in a business rescue scenario, the research aim of this article is to establish how the BRP determines the business rescue value of a financially distressed South African company. The aim is addressed by answering the following research question: In business rescue, what valuation approach does the BRP use to determine the business rescue value? In order to answer the research question, the research objective is to determine the valuation approaches used by a BRP under Goal 1 and Goal 2 of a business rescue.

The remainder of the article is structured as follows: a literature review is provided, followed by the research methodology and presentation of the findings. Thereafter, the authors provide a summary of the findings with author recommendations. The article concludes with limitations of the research, possibilities for future research and an overall conclusion.

\section{Literature review}

In a distressed setting, the objective is usually to value the enterprise as a whole, as opposed to only the equity (Altman \& Hotchkiss 2006:105). The term 'reorganisation value' is often used in international commentary in such an instance. Reorganisation value is the fair value of the entity before considering liabilities and approximates the amount a willing buyer would pay for the assets of the entity immediately after the restructuring (AICPA 1990:19, 273, 295). The United States of America (USA) were the first to start with a modern business rescue regime (Rajak \& Henning 1999:263). The USA Bankruptcy Code is divided into various chapters, of which Chapter 11 contains the provisions for reorganisation. Being the leading legislation in reorganisations, one would expect that Chapter 11 would clearly define reorganisation value. However, Steffen (2016:14) noted that reorganisation value is not defined explicitly in the USA, although the reorganisation value is determined primarily by discounting future cash flows for the reformed business (that will emerge from Chapter 11 of the USA Bankruptcy Code), plus the anticipated income from the sale of assets not required in the reconstituted business.

The South African Companies Act does not require the business rescue plan to include a valuation of equity and, therefore, the review below focuses on the main valuation techniques available in valuation theory, with which to value a company (enterprise as a whole). The three main valuation approaches include an income, relative (or multiple) and asset (or cost) approach.

\section{Income approach}

A significant technique under the income approach is the free cash flow to firm technique (FCFF). The FCFF is forward-looking and focuses on future operating cash flows, discounted to a present value using an appropriate discount 
rate to take the time value of money (TVM) into account (Altman \& Hotchkiss 2006:109; Damodaran 2013:7; Harvey 2011:183; TMA-SA 2016:145). This technique has two main underlying expectations, namely that the company will be a going concern and that the company will generate profits for some time in the future (Buttignon 2015:6; TMA-SA 2016:152). The latter requires a terminal value, calculated by either using a multiple of revenues (usually derived from healthy, publicly traded firms) (Damodaran 2009:31), the Gordon growth model or, if it is a deteriorating or finite-lived asset that is valued, the salvage value of the asset (IVSC 2016:43). In SA, under usual business circumstances, valuators tend to use the income approach to value a going-concern company (PwC 2017). The study conducted by PwC (2017), however, did not prescribe the approach to use under business rescue circumstances.

Alternative valuation techniques to consider under the income approach are the adjusted present value (APV) technique and the modified discounted cash flow (MDCF) technique. The APV might be useful in complicated tax situations and during significant changes in the capital structure (Altman \& Hotchkiss. 2006:113; Poniachek 2010; TMA-SA 2016:151). The MDCF technique may also be useful as it separates a going-concern value and a value that emerges from the effects of distress (Damodaran 2006:15; TMA-SA 2016:152).

\section{Relative (or multiple) approach}

The relative (or multiple) approach uses a comparative company or industry average or multiple (e.g. profit after tax times 4 equals company value) as a proxy to determine a value for a specific company. Aspects to consider when searching for a peer group multiple include variables such as revenue, earnings, customers, product mix, distribution channels and financial leverage (TMA-SA 2016:157). The lack of comparable entities might, however, hinder the estimation of a peer group multiple (Crystal \& Morkal 2006:8; Harvey 2011:187). Furthermore, the company in financial distress will probably have negative cash flows and profits, which will result in a negative value. Beyond the difficulties of finding the proxy multiple, the usefulness of historical data for the firm is limited when the firm undergoes significant asset restructuring (Altman \& Hotchkiss 2006:106). Under usual business circumstances, PwC (2017:54) found that of all the different multiples available, the market value of invested capital, divided by earnings before interest, tax, depreciation and amortisation (MVIC/EBITDA) multiple, is the most frequently used multiple in order to value a going-concern entity in practice.

\section{Asset (cost) approach}

The final main valuation approach considered, is the asset-based valuation, also known as the cost approach (IVSC 2016:45; PwC 2017:30). This approach is not typically used to value a company or business as a whole (IVSC 2016:54) although the cost approach is often used as a reasonableness check to confirm that the going-concern value is more than the liquidation value (IVSC 2016:45). Under the asset approach, a valuator may use different valuation techniques. Three of the most common techniques are replacement cost, reproduction cost and the summation (sum of the parts) method (IVSC 2016:46-48). It is important to note that the carrying value (alternatively referred to as the book value) of assets as per financial statements is typically cost price, less accumulated depreciation and accumulated impairment losses. This carrying value may thus not be the same as the realisable value (IVSC 2016:46-47).

\section{Summary of conventional valuation approaches and techniques}

Before considering other valuation considerations in the South African context, a summary of the conventional valuation approaches and the main valuation techniques, identified from the literature is provided (Figure 1). The findings of the study will be contrasted against the conventional valuation approaches and techniques indicated in Figure 1.

\section{Other valuation considerations}

Besides the specific valuation approach and technique used to value a company, other qualitative factors may also influence the valuation of a financially distressed company in business rescue.

\section{Who determines the business rescue value?}

In a valuation, the different parties (e.g. the shareholders, managers, the BRP and creditors) might have different needs and bargaining power (Correia et al. 2015:6-2; PwC 2017:17). This might lead to an agency problem (Jensen \& Mechling 1976). Internationally, under pre-pack asset sales, assets are usually valued by company management or an independent valuator (Mkondo \& Pretorius 2017:104, 116). The conflicting interest between various role players of distressed firms might, however, result in valuation errors ranging from less than $20 \%$ to greater than 250\% (Gilson, Hotchkiss \& Ruback 2000:70).

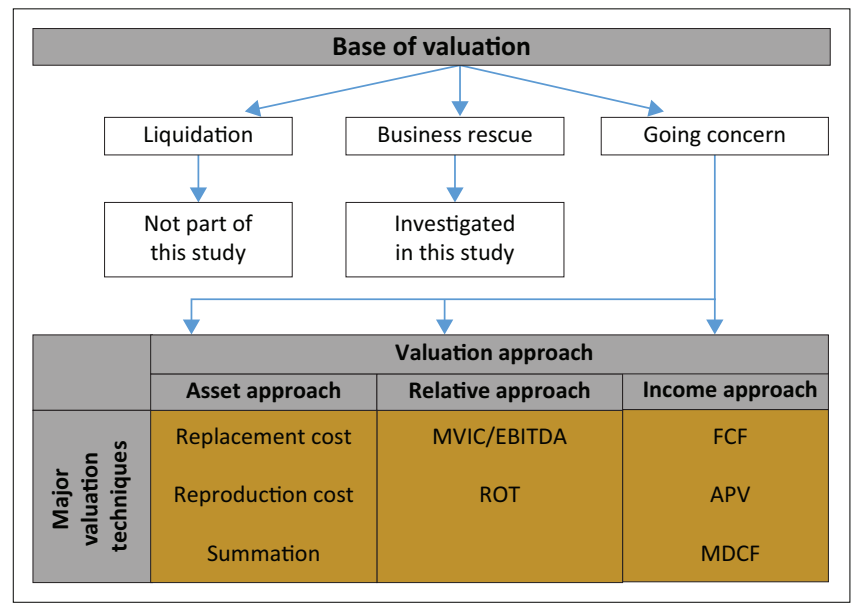

MVIC/EBITDA, market value of invested capital divided by earnings before interest, tax, depreciation and amortisation; ROT, rules of thumb; FCF, free cash flow; APV, adjusted present value; MDCF, modified discounted cash flow.

FIGURE 1: Valuation approaches and main valuation techniques. 


\section{Time value of money}

Time value of money should be explicitly considered in the valuation of distressed companies because reorganisations may take several years (Altman \& Hotchkiss 2006:8; Reilly 2013:13). The TVM is reflected in the discount rate. However, determining the cost of capital components (e.g. the cost of debt, cost of equity, debt-equity ratio) and resulting weighted average cost of capital (WACC) discount rate might be difficult (TMA-US 2016:212). The average expected business rescue period for South African companies is 16 months (Klokow 2018:7). One would, therefore, expect the BRP to consider the TVM, given that people prefer to receive money sooner rather than later (Adriaanse \& Van der Rest 2017:104).

\section{South African context}

The reader should note that the theory in this section was drawn from the work of various international researchers, for example Altman and Hotchkiss (2006), Damodaran (2009), Reilly (2013) and TMA-US (2016). It is important to note that these researchers were writing primarily from the point of view espoused in the USA (Chapter 11 of the USA Bankruptcy Code). An important difference between business rescue in SA (Chapter 6) and business rescue in the USA is that a company does not have to be in financial distress to file for Chapter 11 protection, whereas, in SA, a company must be in financial distress in order to do so. Chapter 6 is also the only legislation, when compared to the USA, Canada, the United Kingdom and Australia, that includes a strict definition of financial distress, namely that within the following six months, the company will be unable to pay its debts or the company's liabilities will exceed its assets (Lamprecht 2016:113).

\section{Theoretical perspective}

Within a constructivist ontology, and taking an inductive interpretive approach to understanding the nature of valuations in a business rescue context, two main theories were used to guide the research, namely agency theory and information asymmetry. Firstly, agency theory is a well-known theory that describes the relationship in which one or more persons (the principal) engages with another person (the agent) to perform some service on the principal's behalf. This may involve delegating a degree of decision-making power to the agent. However, within agency theory, an agency problem may occur when the parties to the relationship have different goals (Jensen \& Mechling 1976). An agency problem often occurs between the shareholders and management of a company, as well as between the shareholders and providers of finance (Correia et al. 2015). In the context of business rescue, Pillay, Rajaram and Ramnanun (2020) argued that because agency theory describes the affiliation between agents (BRPs) and principals (the companies they assist), business rescue falls within the agency theory. Pretorius (2016:483) agrees that an agency problem exists between the various role players (shareholders, BRPs and creditors) in business rescue, due to the different degrees of the risk appetite of these role players. Shareholders' influence over the choice of supervisor might be limited, shareholders will not be able to vote on the proposed plan unless their rights are amended, and even then may find their opposition to a plan, that is supported by the creditors, ignored. The prevailing view is that shareholders in a company rescue are mainly onlookers, although they may be the ones who will lose everything (Loubser 2008:389). Also, it is impossible to say with any certainty whether the legislature considered the fact that directors could also be employees of the company and thus be entitled to the special rights, powers and super preferences that are given to employees in business rescue proceedings. In the absence of any provision, clearly excluding executive directors from being regarded as employees, it must be assumed that they have all the rights, powers and benefits that any other employees have during business rescue proceedings, even if that position may lead to abuse of the process or have other undesirable consequences (Joubert \& Loubser 2016).

Secondly, and following from the agency theory, is that classic agency theory also assumes the existence of equal information to the principals and agents (Pretorius 2016). In his seminal paper, Akerlof (1970), explains the theory of information asymmetry between buyers and sellers in relation to the value of a product. In the context of business rescue, Pretorius (2016), Levenstein (2015) and Deloitte (2017) confirmed the existence of information asymmetry.

In this article, the authors use agency theory as a lens to consider whether the BRP is acting for its own benefit, for the benefit of the shareholder, or maybe even for the creditor. Furthermore, the theory of information asymmetry is used to consider what information is shared between the BRP and potential investors for each party to determine the business rescue value.

\section{Research methodology Philosophical view}

Research studies are influenced by the beliefs, values and philosophical assumptions of the researchers. The ontology of the researchers was that of constructivism, with the research participants and their subjective views forming the researchers' understanding of the research phenomena. Within this context, the research participants provided their own understanding and ascribed meanings shaped by their interactions with others and from their own personal histories. The research findings in this instance are shaped from individual perspectives to broad patterns and, eventually, to broad understandings (Creswell \& Plano Clark 2011:40).

\section{Research approach}

In view of the limited body of research on valuations in a South African business rescue context, the research approach was of an exploratory, qualitative nature. A semi-structured interview method was used to obtain the views of 11 senior BRPs. Given the topic of valuations, the respondents were 
purposefully selected (Rowley 2012:264) to include mainly individuals with a financial background. The remainder of the sample was selected from boutique consulting firms, based on seniority and experience in the business rescue field (e.g. someone who led high-profile business rescues in SA or someone recognised as a leader in the industry by their peers). The selection process resulted in most of the research participants being senior BRPs, having an accounting background and registered with at least one of the major accounting bodies (Chartered Institute of Management Accountants [CIMA], South African Institute of Chartered Accountants [SAICA] and South African Institute of Professional Accountants [SAIPA]).

The literature review was used to prepare an interview agenda for the study. The interview agenda was pilot tested (Bryman 2012:185) to ensure the questions were clear and relevant, and that they addressed the research question (Rowley 2012:265). The pilot testing was followed by semistructured, one-on-one interviews with individual BRPs. As suggested by Rowley (2012:265), the interviews were conducted in person. The semi-structured interviews permitted a degree of flexibility (King \& Horrocks 2010), and BRPs had the opportunity to share information about their personal beliefs, experiences and actions, which may not have been possible if a rigid schedule of questions had been used (Stone 2015:259). When needed, the researcher asked additional questions in direct response to the statements made by the interviewee (Bryman 2012:471). The researcher conducted the interviews until data saturation occurred (Guest, Bunce \& Johnson 2006:59). In this study, data saturation was reached after 10 interviews, with an 11th interview as the concluding interview. The interviews took between 48 and $85 \mathrm{~min}$, with an average length of $60 \mathrm{~min}$. The number and length of the interviews were deemed to be sufficient, compared to a recommended six to eight interviews of 1 hour each (Rowley 2012:263).

All interviews were audio-recorded. In addition to the audio recordings, the interviewer also made written notes during and shortly after each interview, based on personal reflections in relation to important statements and observations (Ritchie et al. 2013:297; Rowley 2012:266). Subsequent to each interview, a professional transcriber transcribed the audio recordings in order to prepare the audio data for computerassisted analysis (Creswell \& Plano Clark 2011:205). Atlas.ti was used to code the transcriptions and personal notes into key themes, concepts and ideas using an inductive mode of reasoning (Bryman 2012:404). An immersion approach (Stone 2015:259) was used through direct engagement with the coding and thematic analysis process. This involved repeatedly replaying the audio recordings and revisiting the transcripts and notes made during the interviews. The researchers were aware that a theme might be unique to one interviewee's account (King \& Horrocks 2010). After coding all the interviews, Atlas.ti was used to group specific codes together to form conceptual frameworks based on common themes identified from the different interviews. This rigorous thematic analysis process of data familiarisation, data coding, theme development and revision (Creswell \& Plano Clark 2011:205), provided the necessary rich information and findings in order to achieve the research objectives and to answer the research questions.

Researcher bias can be a factor in qualitative research such as interviews (Rowley 2012) and threaten the reliability of data. In this study, the researcher ensured that only experienced interviewees were chosen, that the interview agenda was appropriately designed and tested and that a thorough analysis of the data was performed, resulting in reasonable assurance of the reliability and validity of findings (Creswell \& Plano Clark. 2011; Rowley 2012). To ensure the trustworthiness of the research, that is, credibility, transferability, dependability and confirmability (Lincoln \& Guba 1985), the researchers employed the following process. The credibility of the findings was ensured by site triangulation (Shenton 2004:66) and by selecting participants from several organisations and different provinces. To ensure transferability, the researcher provided a 'thick description' of both the participants and the study's context (Lincoln \& Guba 1985). An in-depth methodological description enhanced dependability (Shenton 2004:73), while the secure storage of all the notes, transcripts and audio recordings ensured the confirmability of the findings (Milne \& Oberle 2005:416).

\section{Ethical considerations}

This article followed all ethical standards for carrying out research. Stellenbosch University approved the study with ethical clearance number: ACC-2018-6328.

\section{Findings}

Interviewees indicated that a single business rescue plan might include a combination of Goal 1 (continue to exist) and Goal 2 (BRIL) proposals, especially if it is a business rescue of a large entity. It is important that the reader keeps in mind the fundamental difference between a Goal 1 and a Goal 2 business rescue because the research found that the goal affects the valuation approach followed by the BRP. The next section presents the valuation techniques used under a Goal 1 scenario.

\section{Valuation techniques used to determine the business rescue value under Goal 1: Returning the legal entity to solvency}

The study found that under a Goal 1 scenario, participants deem traditional valuations according to valuation theory irrelevant. In order to present a business rescue value in the plan, the BRP will, after performing a critical trading analysis of the distressed company, prepare a cash flow projection, which will usually be for only 3 years, unless there are compelling reasons that require longer cash flow budgets. Company management will assist with the cash flow projection only if the BRP is satisfied that management is competent to do so. However, interviewees indicated that 
management is often incompetent in preparing proper cash flow budgets. The study revealed that BRPs did not discount the projected cash flows to account for the TVM; neither did the BRPs calculate a terminal value for the business. Their aim was to ascertain when, and how much cash will be available to creditors from the ongoing trade of the company, in order to provide a reasonable return to both old and new creditors:

'Typically that valuation on the outcome is just a pure maths calculation, it says there's R5 000 a month for 60 months. It's not so much a valuation as just an exercise in really crunching the numbers, and it's the free cash flow part, before the discounting if you work it out, but very granular.' (BRP9, July 2018, chartered accountant)

The statement above indicates that the valuation is not a genuine valuation but rather a possible valuation which the BRP needs to achieve to proceed with business rescue. To incorporate risk in the valuation calculation, some BRPs indicated that they use scenario analysis and provide a high and low valuation scenario in the plan, while the majority do not provide different scenarios in the plan:

'I give two scenarios, business rescue and liquidation, which one do you want.' (BRP5, June 2018, chartered accountant)

It is important to manage the expectations of the creditors, and thus, the BRPs preferred to be conservative, by using the lower or average range of values when preparing cash flow forecasts:

'Under promising and over-delivering rather than the converse.' (BRP5, June 2018, chartered accountant)

To continue trading, the financially distressed company may require a new equity partner in order to obtain post-commencement finance (PCF). Although BRP10 had obtained an independent valuation from an independent auditing firm for the equity value of a distressed company once, the majority of the BRPs indicated that a business in rescue generally has a negative equity value. Thus, BRPs can usually only work with the offers they receive from potential investors:

'You are going to work with what you have. Regardless of the value of the business, you [the new investor] are going to want the lion share. You [the new investor] are going to say listen, I will put in 50 bobs, but I am going to take $60 \%$. This business's value two years ago was sitting at, you know, a billion. How can you expect to ... I say well, take it or leave it. There is a sanity check calculation in the background that might give you an idea of what equity value is, but in most cases, a business in rescue has negative equity.' (BRP6, July 2018, business administrator)

The above statement shows the negative effect that the lack of PCF (Du Preez 2013) has on the business rescue value. Because of the dependency on private investor capital, the bargaining power to negotiate a high equity value is limited. It also highlights the agency problem as identified by Pretorius (2016), as a BRP will sometimes need to accept PCF from a private investor, in return for an equity stake, just to save the company's operations (and employment).
The BRP (agent) therefore focused on saving the business operations, and not necessarily on retaining current ownership of the shareholders (principals).

One interviewee, BRP7, follows a specific recipe when pursuing Goal 1 with a new equity partner. During a critical trading analysis of the financially distressed company, BRP7 would investigate current expenses line by line on the company's trial balance and be ruthless in cutting costs. They believe that, if an operating leverage of $20 \%$ exists (i.e. the difference between the company's old and new cost structure), the business may be saved in terms of Goal 1. It is then important to establish how much working capital the company needs to keep on trading and to consequently find a funding partner for the required working capital. The funding partner will then, in return, receive an equity stake in the company. Figure 2 is an example of a standard PCF agreement used by BRP7 when selling shares under business rescue to a new equity partner.

From Figure 2, the ability of the BRP to critically analyse the short-term cash flow needs of the company in detail is evident. This critical analysis of future cash inflows and outflows will determine both the PCF, as well as the business rescue value of the company (the higher the $\mathrm{PCF}$, the higher the business rescue value). Also, it is important to note that the business rescue value under Goal 1 will be fluent: it is not an exact value that is determined, because the business rescue value represents in essence the potential cash that the business will generate over a specified time period.

Previous literature confirms that SARS has a preferent claim in liquidation but a concurrent claim in business rescue (Werksmans 2012). Business rescue practitioners indicated that during the pre-assessment of the company, the voting percentage of the South African Revenue Service (SARS) is a 'game-changer' in respect of the business rescue value:

'If SARS has more than $25 \%$ voting interest, then at the meeting they are going to have a swing vote. So, where you guys want to value the company, I'm valuing the [SARS] vote. If yes [SARS's vote is more than $25 \%$ ], we look at the liquidation calculation. If SARS is going to get 70 cents in liquidation, then, using the free cash flow method, I have to pay all the concurrent creditors the same [in business rescue], even if they are getting zero cents [in

- New equity partner buys $51 \%$ shares in the financially distressed company at a price of R1 for each share.

- New equity partner is required to invest PCF equal to 3 to 6 months working capital need (e.g. property and labour costs for six months). - Financially distressed company pays PCF back to new equity partner over three years, with the prime interest rate applying on the PCF. - After a three-year period, the original shareholders will buy back the new equity partner's $51 \%$ shareholding at a PE-ratio of 3 .

Source: Adapted from BRP7, July 2018, professional accountant.

$\mathrm{PCF}$, post-commencement finance.

FIGURE 2: Post-commencement finance agreement when selling shares to a new equity partner. 
liquidation]. I have to go for 70 cents, so that I can win SARS in court. Then I put that in my cash flow model, and then I work out a value.' (BRP7, July 2018, professional accountant)

In summary, the results of this section stand in contrast to previous literature. Although the FCFF valuation technique was preferred in determining the reorganisation value under international legislation such as Chapter 11 of the USA Bankruptcy Code (Altman \& Hotchkiss. 2006; Steffen 2016), and in ordinary business practice in SA (PwC 2017), the FCFF was not used by BRPs to determine the business rescue value. Instead, BRPs determined the business rescue value by using a short-term (3 years) cash flow budget, without the inclusion of a terminal value for the business. In addition, although it was expected that the BRP would consider the TVM (Adriaanse \& van der Rest. 2017; Altman \& Hotchkiss 2006; Reilly 2013; TMA-US 2016), the findings indicated that BRPs used undiscounted cash flows. Furthermore, the position of SARS was identified as a significant influencer of future projected cash flows and, therefore, the business rescue value.

\section{Valuation techniques used to determine the business rescue value under Goal 2: Sale of business}

As indicated earlier, two scenarios exist under Goal 2 (Harvey 2011:182). The first scenario is to pursue the sale of the business as a functioning unit. When a financially distressed business is sold (either as a group or as separate divisions), it involves a cash transaction and, according to the interviewees, valuations would typically be more relevant in this instance. In a Goal 1 return to solvency scenario, where a definite possibility of returning the business to solvency exists, a liquidator would not be able to perform the task, as a liquidator's task is to close down a business and sell the assets. However, when considering Goal 2 of business rescue, it becomes more of a grey area - this is where one would be able to argue that either a BRP or a liquidator would be able to sell a company or its assets. There is a fine line between use and abuse of the business rescue procedure (Bradstreet 2013), and the authors believe that it is the availability of this secondary goal of the legislation that opens up the door for abuse. It is therefore actually only under Goal 2 where one can really compare BRPs with liquidators.
The business rescue value is collectively determined by certain role players. Table 1 indicates some of the main role players in business rescue and their roles in determining the business rescue value. The table also shows the number of interviewees that mentioned that particular role.

It is evident from Table 1 that, ultimately, the buyer determines the price of the transaction. Participants indicated that the BRP might perform a high-level valuation of the company solely to determine whether the offers that come in are reasonable:

'I was a partner at firm X [a large audit firm], so I know how to do a valuation, and I've done many valuation advisory engagements, and sell-side mandates and buy-side mandates and various things, and that whole normal world doesn't apply, because anybody who is buying a distressed business says it's in trouble, it's failed. You can say it failed because the owner bought a Ferrari with the money; it is not the business's mistake. They [the buyers] say no, then they push you down. So when you talk valuation techniques, I mean, we do them to get an idea, but the value is what a willing buyer is prepared to pay full stop.' (BRP9, July 2018, chartered accountant)

According to interviewees, buyers do not usually disclose their valuation techniques and underlying assumptions, although BRPs are able to ascertain, from the bids coming in, that buyers tend to focus on the value of tangible assets. In SA, when companies file for business rescue, the level of financial distress is already so bad that, according to BRP1, there is not much 'oxygen left in the tank'. As a result, the financially distressed company does not have either much time or the bargaining power in the selling process as in a typical corporate transaction. Since buyers buy the company assets as a functioning unit, the asset value is the value-in-use, as opposed to the liquidation value of the assets. However, buyers still tend to push the price down as low as possible and, in practice, participants experienced that even tangible assets take a haircut:

'There are deep, deep discounts that come in as a result of the fact that the business is in rescue and in distress. Let me give you an idea. To build Company $\mathrm{H}$ from scratch today would cost you R7 billion, but the bid that we got, the value of that bid, was R1.75 billion.' (BRP6, July 2018, business administrator)

TABLE 1: Roles within the business rescue valuation process.

\begin{tabular}{|c|c|c|}
\hline Role & Finding & $\begin{array}{l}\text { Number of } \\
\text { occurrences }\end{array}$ \\
\hline \multirow[t]{5}{*}{ Buyer } & Determines the value of the offer. & 10 \\
\hline & Looks mainly at the value of assets. & 7 \\
\hline & Seeks heavily discounted price. & 5 \\
\hline & Trade buyers and financial buyers have different valuations. & 3 \\
\hline & Does not disclose the valuation technique or underlying assumptions. & 4 \\
\hline \multirow{4}{*}{$\begin{array}{l}\text { Business rescue } \\
\text { practitioner }\end{array}$} & Facilitates the bidding process with the help of an independent advisor where applicable. & 10 \\
\hline & $\begin{array}{l}\text { Performs instinctual valuation using industry pricing models. This involves a combination of discounted cash flows or earnings multiples } \\
\text { on profitable businesses, the book value or insurance value of assets, and calculating an embedded value for a financial services company. } \\
\text { The business rescue practitioner uses this value solely as a sanity check against bids. }\end{array}$ & 10 \\
\hline & Compares offers received from buyers with the help of independent transaction advisors where applicable. & 10 \\
\hline & Compares offers to liquidation value (and controlled wind-down value where applicable). & 10 \\
\hline Management & Makes company information available to business rescue practitioner. & 11 \\
\hline Creditors & Vote on offers in the business rescue plan. & 11 \\
\hline Court & No involvement in determining the value of the sale. & 11 \\
\hline
\end{tabular}


A strong theme identified from the data was that investors investing in financially distressed companies do not pay for the future earnings potential of the company. The value of the company comes down to an asset valuation approach, and BRPs does not separately value the intangible assets of the company:

'So, if you're in a retail operation and you have a bad retailer getting bought by a good retailer, he's going to give you value for the inventory, on the assumption that you haven't bought too badly - you're not sitting on jerseys in summer or costumes in winter - and possibly a value for the lease. Because if you got prime real estate in an area, that is a key component. However, the ability to turn that store into a profitable store, using his intellectual property, he is not going to pay you for as well. So you generally see asset value, plus a very, very small goodwill component coming out of it in terms of that.' (BRP5, June 2018, chartered accountant)

Business rescue practitioner 11 confirmed that in the retail industry, the value would be asset-based and possibly an earnings multiple, but on far smaller multiples than one would see in a traditional going-concern business, and particularly given the risk that's associated with business rescue. As indicated by the examples above, there is a good potential of investing in a financially distressed company in SA, as investors obtain operating companies with all intangible assets attached to it, at bargain prices. At the same time, it set realistic sale expectations for both creditors and shareholders.

Table 1 indicated that the BRP facilitates communications with potential buyers of the financially distressed business. Goal 2 of business rescue allows for a return just above liquidation; therefore, the liquidation value sets the first valuation benchmark. The liquidation value is thus a critical piece of information that can lead to both an agency problem and information asymmetry between role players. The majority of BRPs indicated that the liquidation value is usually independently determined. This is a control that is put in place by BRPs, although not required by the Companies Act. Some BRPs indicated that they did not give the liquidation value to potential buyers, although other BRPs did provide the liquidation value to potential bidders. Business rescue practitioners state that they do not give the liquidation value to prevent potential bidders from exploiting the system (BRP5, BRP6).

The above example indicates that BRPs (agents) do act in the best interest of shareholders (principals) and creditors, in the sense that they try to obtain the highest possible value from buyers by not disclosing the liquidation value. Although information asymmetry between buyers and sellers (Deloitte 2017; Levenstein 2015; Pretorius 2016) is created by the non-disclosure of the liquidation value, it enables the BRP (agent) to obtain the highest possible business rescue value for the business, which reduces the agency problem.

To summarise, this section discussed several themes in relation to valuation in a Goal 2: selling of a business, scenario. The main findings included the following:
- The buyer determines the value of the entity. This value is usually heavily discounted, and based on the value of physical assets, not on the future earnings potential of the distressed company. This confirms the findings by Roslynn-Smith, De Abreu and Pretorius (2020:40) that assets are sold for a value between forced sale value and market value during business rescue proceedings.

- The BRP may perform an instinctual valuation for the distressed company, using a combination of conventional valuation techniques. However, BRPs indicated that this instinctual valuation has little relevance.

- Business rescue practitioners used various types of bidding processes, with a varying degree of sophistication.

- Liquidation value is independently determined.

The selling of the business as a functioning unit is only one way of achieving a BRIL in business rescue. Under Goal 2, some BRPs also make use of a controlled wind-down, as explained below.

\section{Valuation techniques used to determine the business rescue value under Goal 2: Controlled wind-down}

The second scenario under Goal 2 entails that the BRP sells the company's assets over a specified period and then closes the company and business. Table 2 specifies the benefits that this type of business rescue has for the creditors, as opposed to the selling of assets by a liquidator (under liquidation). The table also shows the number of BRPs that mentioned that aspect.

As illustrated in Table 2, the four most notable reasons that a BRP can create more value under a controlled wind-down in business rescue, as opposed to a liquidator in liquidation circumstances, are:

- Cost savings - BRPs are reimbursed on an hourly basis, while liquidators ask a prescribed percentage of the value of the assets sold. According to one BRP, this would mostly be an advantage for companies with for example

TABLE 2: How the business rescue practitioner creates value through a controlled wind-down.

\begin{tabular}{lc}
\hline Theme & $\begin{array}{c}\text { Number of } \\
\text { occurrences }\end{array}$ \\
\hline BRP fees are considerably lower than liquidator's costs. & 8 \\
$\begin{array}{l}\text { Business rescue period is much shorter than the liquidation period } \\
\text { (time value of money consideration). }\end{array}$ & 5 \\
$\begin{array}{l}\text { BRP can sell the assets at market-related sales (e.g. a discount to } \\
\text { selling price) in business rescue, as opposed to a fire sale } \\
\text { (e.g. discount to cost price) in liquidation. }\end{array}$ & 4 \\
$\begin{array}{l}\text { The BRP and their team have more capabilities as compared to } \\
\text { a liquidator (e.g. more efficient in collecting debtors) and can } \\
\text { institute proper controls while trading. }\end{array}$ & 6 \\
$\begin{array}{l}\text { It is possible to limit the creditor base. Business rescue does not } \\
\text { create further liabilities (e.g. rehabilitation costs in mining and } \\
\text { milling industries; contingent risks for guarantors in the } \\
\text { construction industry). }\end{array}$ & 3 \\
$\begin{array}{l}\text { The BRP has access to quality information (e.g. consumer buying } \\
\text { trends) and can plan a detailed closing down strategy with the } \\
\text { existing management team. }\end{array}$ & 2 \\
$\begin{array}{l}\text { The BRP can use seasonal cycles (e.g. sell agricultural products } \\
\text { before they expire). }\end{array}$ & 2 \\
$\begin{array}{l}\text { Assets are preserved and properly maintained and, therefore, } \\
\text { the assets retain their value. }\end{array}$ & 2 \\
\hline BRP business rescue practitioner. & \\
\hline
\end{tabular}

BRP, business rescue practitioner. 
high-value real estate, because it would mean that even though the real estate assets are sold for exactly the same value in business rescue as in liquidation, the business rescue value will exceed the liquidation value because the BRP does not get a prescribed percentage of the assets sold:

'On immovable property he's [the liquidator] going to take his $3 \%$ plus VAT on the sale of the property, which could be, if you're selling a property for 100 million, well, thank you very much, that's a nice fee $-\mathrm{R} 3$ million. That's a lot of time I'm going to have to spend as a practitioner to make that kind of fee.' (BRP10, July 2018, chartered accountant)

- Timing - In business rescue, there are no time constraints to pay out business rescue dividends. A liquidator only pays dividends once the Master of the High Court has approved the distribution account. The acting Chief Master, Tessie Bezuidenhout, recently confirmed that liquidations in SA take too long. In the USA, simple cases are finished within 6 months while, in SA, such cases may take 10 years (SARIPA 2018).

- Market-related value - Although the valuation approach is still an asset approach, it is the value-in-use of the asset sold piecemeal as opposed to the forced sale value. This statement is illustrated by the following comment:

'The value of the stock itself is higher, this jacket for sale at the Victoria \& Alfred is going to be R5000, stuck in a box, being auctioned with 100 other jackets it's going to be 50 bucks.' (BRP5, June 2018, chartered accountant)

- The capabilities of the BRP and their team (discussed in more detail below).

A BRP may sometimes pursue Goal 1, but then the creditors do not approve the business rescue plan. This situation may then result in either a liquidation or a controlled wind-down under business rescue. The authors believe that the agency problem features very strongly in such an instance since the BRP (agent) was appointed by the shareholders or directors (principals) with the belief that the BRP would be able to save their shareholding, but due to lack of creditor support of the plan, the BRP is forced to act against the instruction of the principal, and pursue a controlled wind-down. A notable finding in relation to maximising the value under a controlled wind-down was the capabilities of the BRP. The interviews revealed that BRPs have remarkable business acumen (e.g. innovation and creative abilities), digital acumen (e.g. data analytics) and relational acumen (e.g. communication and leadership skills), which enable them to unlock value from a financially distressed business. Furthermore, BRPs also find themselves in better circumstances than a liquidator. For example, BRPs might obtain employee support during the business rescue, the Companies Act allows the BRPs a vast amount of freedom and the public perception of business rescue compared to liquidation is better. Business rescue practitioner 9 explained that after working with a company for a while, trying to save it, the BRP would have developed a relationship with the management and employees, and gained access to valuable company data. This puts the BRP in a much better situation to extract value from the company than a liquidator.
'I worked with the operational director and the financial director for six months trying to rescue it [the group of companies], and now I was able to say to them right, we need to change our thinking. And because you've built up a working relationship, you can run that. A liquidator comes in, and he doesn't even know what's available to him, whereas I was able to say shouldn't we start pairing our discounts, because I'd analysed the business. That's why the wind-down works better in rescue. Because as a practitioner, you've got to be more imaginative than a liquidator. A liquidator opens his toolbox, he sees a hammer, and that's all he's got, whereas we've got the freedom to do more because of the Act. Your best employees are not going to hang around to work with the liquidator.' (BRP9, July 2018, chartered accountant)

The findings indicated that BRPs have the authority to use assets in the ordinary course of business in order to generate a profit and can, therefore, utilise seasonal cycles to obtain higher asset values. A provisional liquidator has no authority to sell assets while the company is under provisional liquidation. Assets are disposed of only after the final liquidation order at a forced sale value. Many businesses are sensitive in relation to seasonal cycles. For these businesses, the value of inventory is entirely dependent on the utility it may have at a particular time of the year. For example, sales in the retail sector usually spike over the festive season in December, while in agricultural retail products may expire if they are not sold during the harvest seasons. If the BRPs can sell assets while it is the high season or close to harvest time, it should be possible to sell the assets at a higher value as compared to a liquidator who missed the season:

'You have to be quite smart in how you operate to get a better value than liquidation. Otherwise, everybody would do this. We closed [number] furniture stores, in three months in Company E. We were lucky because it was over November, December, January, and our philosophy were on the last day, as you shut the store and therefore cut your operating costs, you give away the last piece of furniture. So, you start at full retail price, and you tweak your discounts because you're burning, I mean, you're burning [amount] in rent, over that three-month period. So, if you're open for four months, you're doing worse than that [liquidation].' (BRP 5, June 2018, chartered accountant)

The findings further revealed that in business rescue, as opposed to liquidation, it is possible to limit the creditors base, which increases the business rescue value. For example, in the event of the liquidation of a construction business, all construction contracts would be terminated, resulting in the crystallisation of the guarantees as liabilities for the company. In business rescue, the completion of construction contracts and the resulting cancellation of guarantees eliminate the risk of these guarantees crystallising as liabilities of the financially distressed company, and thus this gives rise to higher business rescue dividends. Business rescue practitioners were of the opinion that they were able to preserve considerable value for creditors in construction type businesses by using the ring-fencing of debtors technique. This technique results in the construction company being left to trade under business rescue. The BRP then completes the ring-fenced construction projects by utilising 
the company's construction records and its own employees. After completion of the construction projects, the BRP collects the retention monies from existing construction debtors and pays the creditors from the proceeds:

'We worked out a complete plan where we ring-fenced all the debtors, saying we are going to incur legal costs to collect this, but in the meanwhile, the business has been relieved of all this debt, that's all you will be paid.' (BRP1, May 2018, attorney)

Each contract and the expected amounts to be collected from the construction debtors are disclosed by the BRP as an indication of the business rescue value. Business rescue practitioner 1 had even gone as far as to provide a guarantee to the creditors, equal to the projected liquidation dividend. Thus, the creditors did not take on any risk of losing the liquidation dividend if they approved the business rescue plan. The excess cash collected in terms of the business rescue plan could, therefore, be seen as a top-up or 'agterskot' to the secured liquidation amount.

In order to use the ring-fence technique, the BRP requires operational cash flows to complete construction projects and to collect debts from the construction debtors. Operational cash flows may come from either the construction company's guarantee provider or an investor who buys the company:

'You might go to your guarantee provider, like Lombard or Credit Guarantee and say if I stop, they're [the clients] going to pull the guarantee and you're just a creditor who is going to get nothing, whereas if you help fund it and give the client comfort, we will finish it. Your liability goes away because that guarantee is not called, the project is finished, and I've got some cash in the door.' (BRP9, July 2018, chartered accountant)

To summarise, a Goal 2, controlled wind-down, business rescue plan can result in a higher asset value compared to liquidation for the following main reasons:

- Market value: The BRP obtained market-related prices for the assets as opposed to fire-sale prices in a liquidation scenario. The valuation approach followed is thus an asset approach, and contrasts the reorganisation value which is determined primarily by using the income approach of valuation (Altman \& Hotchkiss 2006; Steffen 2016) and ordinary South African business practice (PwC 2017).

- Timing: Business rescue dividends can be paid earlier than liquidation dividends. This finding was quite interesting, because previous literature indicated that reorganisation might take several years (Altman \& Hotchkiss 2006:8, Reilly 2013:13). In SA, therefore, it is not only the business rescue value but also the liquidation value that should be discounted to account for TVM.

- Cost savings: BRP fees are less than liquidator costs, thus even though assets might be sold at relatively the same market value, the business rescue value will be higher than the liquidation value because the cost of realising the assets is lower if this is done by a BRP.

- The expertise and capabilities of the BRP can significantly increase the asset value realised.

\section{Summary of findings and authors' recommendations}

The aim of the study was to determine the valuation approaches used by BRPs under a Goal 1 and Goal 2 scenario in South African business rescue. The study used constant comparative thematic data analysis which allowed the researcher to identify significant themes relating to the valuation techniques and other valuation-related considerations concerning the business rescue value. Although the valuation of the debtor as a continuing entity and the resulting reorganisation value is at the centre of the reorganisation plan in the USA and several other countries (Altman \& Hotchkiss 2006:33), this study found that it is not the case in SA. The business rescue value is determined in a different manner from the Chapter 11 reorganisation value. The research found that in SA, the goal of business rescue affects the valuation approach followed by the BRP. The study provided evidence that indicated that under Goal 1, return to solvency circumstances, a short-term (3 year), undiscounted cash flow budget is prepared by the BRP to determine the business rescue value, without the calculation of a terminal value, with the voting position of SARS influencing the projected cash flows and therefore the business rescue value in a significant way. In addition, under the Goal 2 business rescue scenarios, the study provided evidence that an asset approach is followed to determine the business rescue value. The study supports previous research by Pretorius (2016) and Pillay et al. (2020) regarding the agency problem. Business rescue practitioners might decide to sell a company under Goal 2 in order to save a business, even if it means that current shareholders will lose ownership. However, under Goal 2, BRPs advised that the liquidation value should preferably not be disclosed to buyers. Although this led to information asymmetry between the buyer and the seller, it assists the BRP in obtaining a higher asset value, which in return reduces the agency problem.

Figure 3 illustrates and summarises the main valuation approaches and valuation considerations used to determine the business rescue value in practice.

Finally, Figure 4 provides an overarching summary. Figure 4 draws from the findings of the approaches used in business rescue (as depicted in Figure 3) and juxtaposes the findings with the summary of the valuation approaches and main valuation techniques generally used for going-concern entities (as depicted in Figure 1).

Figure 4 illustrates that the asset valuation approach is mainly used in a Goal 2 business rescue valuation, as opposed to the relative or income approach, which is most often used in going-concern circumstances. Under Goal 1, the BRP uses cash flow budgeting techniques to prepare a short-term, undiscounted cash flow projection.

After considering the current valuation practice, as indicated in Figure 3 and Figure 4, the authors make the following 


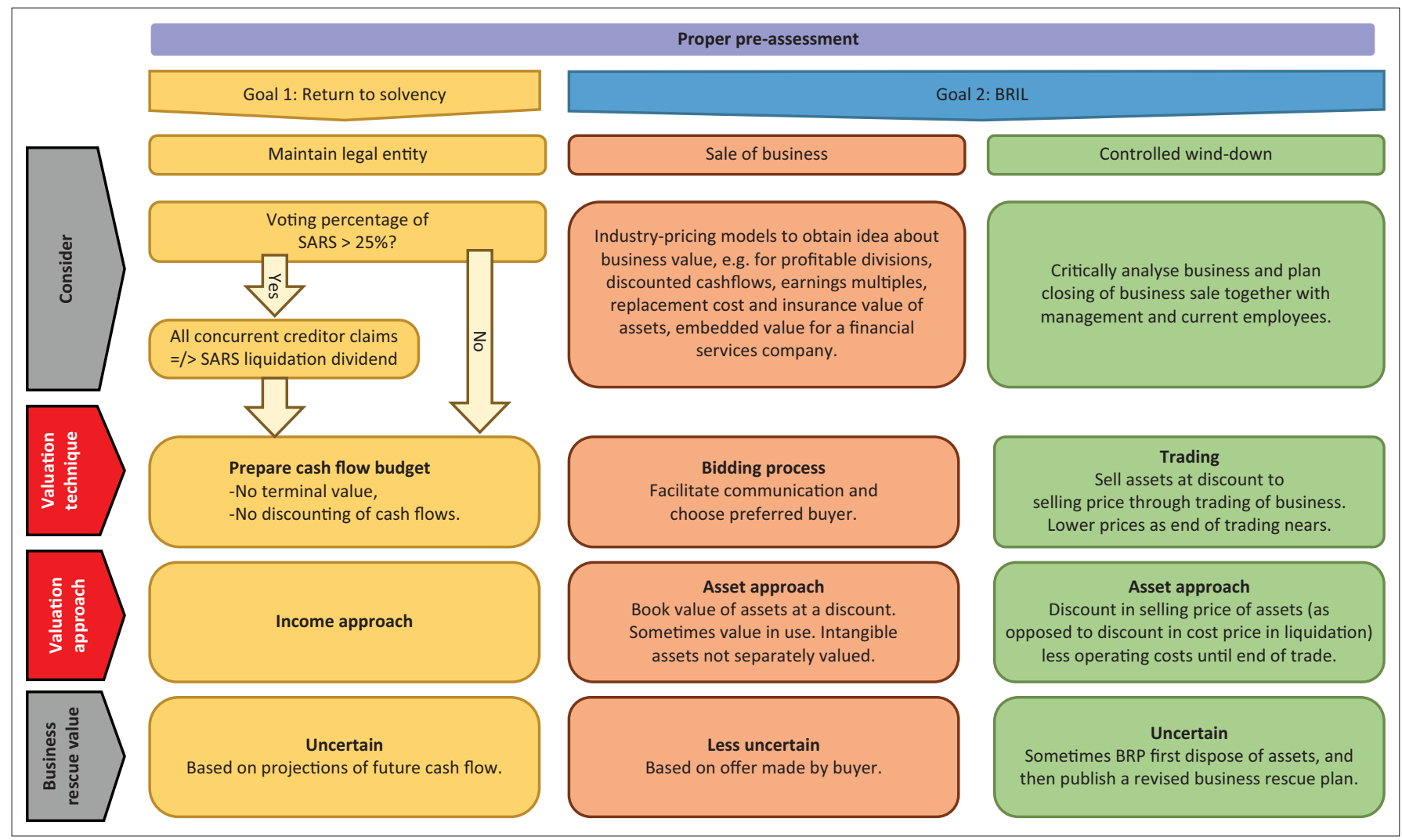

BRIL, better return than immediate liquidation; BRP, business rescue practitioner; SARS, South African Revenue Service.

FIGURE 3: Valuation approaches and other valuation considerations.

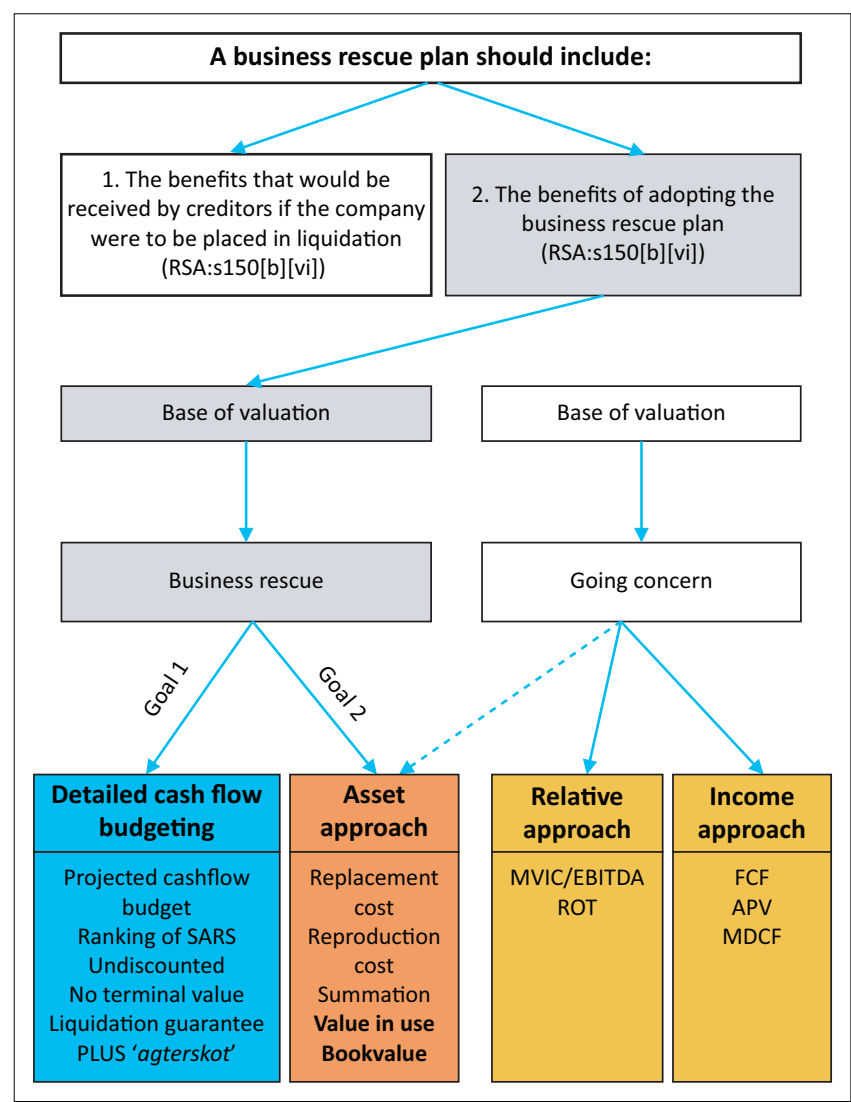

RSA, Republic of South Africa; SARS, South African Revenue Service; MVIC/EBITDA, market value of invested capital divided by earnings before interest, tax, depreciation and amortisation; ROT, rules of thumb; FCF, free cash flow; APV, adjusted present value; MDCF, modified discounted cash flow.

FIGURE 4: Valuation approaches used in business rescue. recommendations. Firstly, it is recommended that BRPs consider TVM, by discounting both the liquidation value and business rescue value using, for example, the current prime interest rate plus a risk premium. From a valuation perspective, this is theoretically more accurate, and it will make a comparison between the business rescue value and liquidation value easier and more suitable. Secondly, we recommend that under Goal 2: sale of business scenarios, BRPs calculate the instinctual valuation with due care, as this valuation assists the BRP with the correct decision-making, a required competency of the BRP (Pretorius 2014). Thirdly, although the findings indicated that BRPs did not calculate the value of equity, the authors recommend that BRPs calculate the value of equity of at least profitable divisions of the business. Given the vital role that PCF plays in the success of business rescue (Britz 2018:131; Calitz \& Freebody 2016; Du Preez 2013; Noomé 2014; Prior 2014:71; Reineck 2015; Vanderstraeten 2016:25), a proper equity valuation might attract potential investors.

\section{Limitations of the study and possible future research}

In view of the nature of qualitative research, it was possible that the findings made during the study may have been affected by the interpretation bias of the authors. This bias was, however, minimised by providing thick descriptions of participant responses. Another limitation of the study was the fact that only BRPs were selected as research participants. As indicated in the findings, potential buyers do not usually 
disclose their valuation calculations to the BRP. Thus, further studies that involve interviews with successful bidders in distressed companies may provide a different perspective as compared to the findings of this study. Lastly, the business rescue industry is prone to a significant lack of formal training in the field of turnaround (Pretorius 2014). The researcher, however, minimised this limitation to the study by carefully and purposefully selecting only participants with the appropriate professional background and with sufficient experience in turnaround practice.

Various opportunities for further research exist in the field of business rescue. Participants mentioned that a business rescue plan might show the 'best valuation' possible, but that understanding why creditors vote either for or against a business plan is an aspect that merits further investigation from a behavioural finance perspective. Another study could also be conducted comparing the actual business rescue dividend paid to creditors to the business rescue value anticipated in business rescue plans, to ascertain the reasonableness of projected business rescue values. Lastly, the findings of this study indicated that BRPs made use of the asset valuation approach and various types of bidding processes. A more granular investigation of the asset approach and further analysis of the bidding processes might provide a better understanding of the valuation phenomena.

\section{Conclusion}

By realising the research aim, the study made valuable contributions in respect of valuation theory, specifically the valuation of a company in business rescue in SA. The findings and recommendations made by the authors may also provide valuation guidelines to newly qualified BRPs and enhance the understanding of the business rescue value by shareholders, creditors and other stakeholders who are inexperienced in business rescue valuations in SA. It appears that the procedures of Chapter 6 of the Companies Act are currently a stumbling block in obtaining an optimal business rescue value. For example, a business rescue value of just above the liquidation value is allowed in terms of Chapter 6. Also, specific regulatory responsibilities of Chapter 6, such as the publication of the business rescue plan within an extremely limited time period together with the requirement of no pre-involvement of the BRP with the business, are counterproductive in obtaining an optimal business rescue value, something that might be reconsidered by the legislator.

\section{Acknowledgements}

A sincere thank you to each business rescue practitioner who participated in this research study.

\section{Competing interests}

The authors declare that they have no financial or personal relationships that may have inappropriately influenced them in writing this article.

\section{Authors' contributions}

S.C. collected, analysed and interpreted the data, as well as drafted the manuscript. C.L. made a substantial contribution to the design of the study, critically revised the manuscript and edited the final version.

\section{Funding information}

This research received no specific grant from any funding agency in the public, commercial or not-for-profit sectors.

\section{Data availability}

The de-identified and summarised data are available, as the original data consists of the opinions and beliefs of the respondents supplied under an agreement of anonymity.

\section{Disclaimer}

The views and opinions expressed in this article are those of the authors and do not necessarily reflect the official policy or position of any affiliated agency of the authors.

\section{References}

Adriaanse, J.A.A. \& Van der Rest, J.P., 2017, Turnaround management and bankruptcy: A research companion, Routledge Advances in Management and Business Studies, Routledge, New York, NY, viewed 18 January 2019, from http://search.ebscohost. com.ez.sun.ac.za/login.aspx?direct=true\&db=nlebk\&AN=1492119\&site=ehostcom.ez.sun.ac.za/l
live\&scope=site.

Akerlof, G.A., 1970, 'The market for "Lemons": Quality uncertainty and the market mechanism', The Quarterly Journal of Economics 84(3), 488-500. https://doi. org/10.2307/1879431

Altman, E. \& Hotchkiss, E., 2006, Corporate financial distress and bankruptcy: Predict and avoid bankruptcy, analyse and invest in distressed debt, 3rd edn., Wiley, Hoboken, NJ.

American Institute of Certified Public Accountants (AICPA), 1990, Statement of position 90-7: Financial reporting by entities in reorganisation under the bankruptcy code, American Institute of Certified Public Accountants, New York, NY.

Bradstreet, R.S., 2013, 'Business rescue proves to be creditor-friendly: CJ Claassen J's analysis of the new business rescue procedure in Oakdene Square Properties', South African Law Journal 130(1), 44-52.

Britz, D.C., 2018, 'Valuing companies under business rescue to attract foreign investors', Doctoral dissertation, University of Pretoria, Pretoria.

Bryman, A., 2012, Social research methods, 4th edn., Oxford University Press, New York, NY.

Buttignon, F., 2015, Distressed firm valuation: Reorganization plan and going-concern capital value, viewed 24 November 2019, from https://ssrn.com/abstract= 2567651.

Calitz, J. \& Freebody, G., 2016, 'Is post-commencement finance proving to be the thorn in the side of business rescue proceedings under the 2008 Companies Act?', De Jure, 49(2), 265-287.

Conradie, S. \& Lamprecht, C., 2018, 'What are the indicators of a successful business rescue in South Africa? Ask the business rescue practitioners', South African
Journal of Economic and Management Science 21(1), 1-12. https://doi. org/10.4102/sajems.v21i1.1726

Correia, C., Flynn, D., Uliana, E., Wormald, M. \& Dillon, J., 2015, Financial management, 8th edn., Juta, Cape Town.

Creswell, J.W. \& Plano Clark, P., 2011, Designing and conducting mixed methods research, 2nd edn., Sage, Los Angeles, CA.

Crystal, Q.C. \& Mokal, R., 2006, The valuation of distressed companies: A conceptual framework, viewed 09 June 2019, from https://papers.ssrn.com/sol3/papers. cfm?abstract_id $=877155$.

Damodaran, A., 2006, The cost of distress: Survival, truncation risk and valuation, viewed 30 October 2019, from https://ssrn.com/abstract=887129.

Damodaran, A., 2009, Valuing distressed and declining companies, viewed 29 November 2017, from http://pages.stern.nyu.edu/ adamodar/.

Damodaran, A., 2013, 'Living with noise: Valuation in the face of uncertainty', Journal of Applied Finance 23(2), 6-22. https://doi.org/10.2469/cp.v30.n4.2

Deloitte, 2017, South Africa restructuring outlook survey results 2017-Seeing through the fog, viewed 26 October 2017, from https://www2.deloitte.com/content/dam/ Deloitte/za/Documents/Corp-Fin/za_Restructuring_Survey_2017.pdf. 
Du Preez, W., 2013, 'The status of post-commencement finance for business rescue in South Africa', Master's dissertation, University of Pretoria, Pretoria.

Gilson, S., Hotchkiss, E. \& Ruback, R., 2000, 'Valuation of bankrupt firms', The Review of Financial Studies 13(1), 43-74. https://doi.org/10.1093/rfs/13.1.43

Guest, G., Bunce, A. \& Johnson, L., 2006, 'How many interviews are enough? An experiment with data saturation and variability', Field Methods 18(1), 59-82. https://doi.org/10.1177/1525822X05279903

Harvey, N., 2011, Turnaround management \& corporate renewal: A South African perspective, Wits University Press, Johannesburg.

Hrdý, M. \& Simek, B., 2012, 'Valuation of the company in financial distress', $E+M$ Ekonomie a Management 15(4), 121-133.

International Valuation Standards Council (IVSC), 2016, IVS 2017 exposure draft International Valuation Standards Council, London.

Jensen, M.C. \& Meckling, W.H., 1976, 'The theory of the firm: Managerial behaviour agency costs and ownership structure', Journal of Economics 3(4), 305-360. https://doi.org/10.1016/0304-405X(76)90026-X.

Joubert, E.P. \& Loubser, A., 2016, 'Executive directors in business rescue: Employee or something else?', De Jure Law Journal 49(1), 95-104. https://doi.org/ 10.17159/2225-7160/2016/v49n1a6

King, N. \& Horrocks, C., 2010, Interviews in QUAN research, Sage, London.

Klokow, C., 2018, Business rescue proceedings status report - 2018, Companies and Intellectual Property Commission, Pretoria.

Lamprecht, C., 2016, 'A financial reporting framework for South African listed companies under business rescue', Unpublished doctoral dissertation, University of the Free State.

Levenstein, E., 2015, An appraisal of the New South African business rescue procedure, University of Pretoria, Pretoria, viewed 01 March 2020, from http://hdl.handle. net/2263/56618.

Lincoln, Y.S. \& Guba, E.G., 1985, Naturalistic inquiry, Sage, Beverly Hills, CA.

Loubser, A., 2008, 'The role of shareholders during corporate rescue proceedings: Always on the outside looking in', SA Mercantile Law Journal 20(3), 372-390.

Loubser, A., 2010, 'The business rescue proceedings in the Companies Act of 2008 Concerns and questions (part 1)', Tydskrif vir die Suid-Afrikaanse Reg 2010(3), 501-514

Loubser, A., 2013, 'Tilting at windmills? The quest for an effective corporate rescue procedure in South African law', SA Mercantile Law Journal 25(4), 437-457.

Marsden, P. \& Laher, L., 2018, [Webcast] 2018 SAICA business rescue breakfast, 19 April 2018, South Africa.

Migwalla, M., 2017, email, 12 January, tommigwalla@deloitte.co.za

Mkhondo, S. \& Pretorius, M., 2017, 'Pre-packaged applications in business reorganisations: International principles', Southern African Business Review 21(1), 98-128.

Milne, J. \& Oberle, K., 2005, 'Enhancing rigor in qualitative description', Journal of Wound Ostomy \& Continence Nursing 32(6), 413-420. https://doi.org/10.1097/ 00152192-200511000-00014

Noomé, J., 2014, 'The sources and obstacles of post-commencement finance in South Africa: A comparison with the United Kingdom and Australia', Master's dissertation, University of Johannesburg, Johannesburg.

Oxford, 2017, Benefit, viewed 26 February 2017, from https://en.oxforddictionaries. com/definition/benefit.
Pillay, S., Rajaram, R. \& Ramnanun, K., 2020, 'Ascertaining the impact of postcommencement finance on business rescue in Kwazulu-Natal, South Africa', The Journal of Social Sciences Research 6(3), 236-244. https://doi.org/10.32861/ jssr.63.236.244

Poniachek, H., 2010, 'Valuation of distressed companies and securities', Valuation Strategies 14(2), 22-27.

Pretorius, M., 2014, 'A competency framework for the business rescue practitione profession', Acta Commercii 14(2), 1-15. https://doi.org/10.4102/ac.v14i2.227

Pretorius, M., 2016, 'The debtor-friendly fallacy in business rescue: Agency theory moderation and quasi relationships', South African Journal of Economic and Management Sciences 19(4), 479-496. https://doi.org/10.4102/sajems.v19i4.1385

Prior, V., 2014, 'A pre-assessment checklist to filing for business rescue in South Africa', Master's dissertation, University of Pretoria, Pretoria.

PwC, 2017, Closing the value gap: Valuation methodology survey 2016/2017, viewed 22 November 2017, from https://www.pwc.co.za/en/assets/pdf/closing-thevalue-gap-2016-2017.pdf.

Rajak, H. \& Henning, J., 1999, 'Business rescue for South Africa', South African Law Journal 116(1), 262-287.

Rajaram, R., Singh, A.M. \& Sewpersadh, N.S., 2018, 'Business rescue: Adapt or die', South African Journal of Economic and Management Sciences 21(1), 1-13. https://doi.org/10.4102/sajems.v21i1.2164

Reilly, R., 2013, 'Construction industry bankruptcy valuations issues', Construction Accounting \& Taxation 23(4), 5-17.

Reineck, J.P., 2015, 'A private equity structure to facilitate the effective post commencement financing of business rescue', Master's dissertation, University of Cape Town, Cape Town.

Republic of South Africa (RSA), 2008, Companies Act, no 71 of 2008, Government Printer, Pretoria.

Republic of South Africa (RSA), 2008, Companies Act, Government Printer, Pretoria.

Ritchie, J., Lewis, J., Nicholls, C.M. \& Ormston, R., 2013, QUAL research practice: A guide for social science students and researchers, Sage, London.

Rosslyn-Smith, W., De Abreu, N.V.A. \& Pretorius, M., 2020, 'Exploring the indirect costs of a firm in business rescue', South African Journal of Accounting Research 34(1), 24-44. https://doi.org/10.1080/10291954.2019.1667647

Rowley, J., 2012, 'Conducting research interviews', Management Research Review 35(3/4), 260-271. https://doi.org/10.1108/01409171211210154

SARIPA, 2018, Western Cape regional seminar, SARIPA, Cape Town, 14 June 2018.

Shenton, A.K., 2004, 'Strategies for ensuring trustworthiness in QUAL research projects', Education for Information 22(2), 63-75. https://doi.org/10.3233/EFI-2004-22201

Steffen, B.J., 2016, 'Reorganization value: What it is ... and isn't', Association of Insolvency \& Restructuring Advisors Journal 30(3), 1-27.

Stone, G., 2015, 'Power, dependence and frustration: A study of power in Australian accountants' advisory relationship with small business', Meditari Accountancy Research 23(3), 250-275. https://doi.org/10.1108/MEDAR-05-2014-0042

TMA-SA, 2016, CRA Course material, Turnaround Management Association, Johannesburg

TMA-US, 2016, Body of knowledge: Accounting and finance, Turnaround Management Association, Chicago.

Van der Straeten, M., 2016, 'Business rescue: Feature', Without Prejudice 16(7), 1-34.

Werksmans, 2012, No preferential creditor status for SARS in a business rescue, viewed 20 January 2021, from https://www.werksmans.com/wp-content/uploads/2018/ 10/155_JN5392Werksmans-Brief_December-2012_SARSinaBusinessRescue.pdf. 